Louisiana State University

LSU Digital Commons

Faculty Publications

Department of Oceanography \& Coastal

Sciences

9-24-2016

\title{
The Changshu Declaration On Wetlands
}

R. Eugene Turner

Jos T. A. Verhoeven

Ania Grobicki

Jenny Davis

Shuqing AN

Follow this and additional works at: https://digitalcommons.Isu.edu/oceanography_coastal_pubs

Part of the Oceanography Commons 


\section{The Changshu Declaration on Wetlands}

Final Resolution adopted at the $10^{\text {th }}$ INTECOL International Wetlands Conference

Changshu, People's Republic of China, 24 September 2016

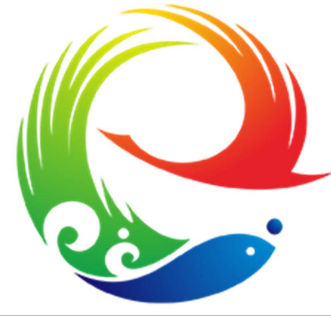

More than 1,200 INTECOL wetlands conference participants from 72 countries, representing a wide range of expertise in wetland science, technology, policy and management, acknowledge the auspicious historical moment in which we have gathered here and come to agreement on the following issues:

Whereas in 2015 all countries agreed the Sustainable Development Goals containing the following three important targets referring to wetlands :

(1) to protect and restore water-related ecosystems, including wetlands, rivers, aquifers and lakes (SDG Target 6.6);

(2) to sustainably manage and protect marine and coastal ecosystems to avoid significant adverse impacts ... and take action for their restoration (SDG Target 14.2);

(3) to ensure the conservation, restoration and sustainable use of terrestrial and inland freshwater ecosystems and their services, in line with obligations under international agreements (SDG Target 15.1);

Whereas development activities have resulted in the loss of more than $40 \%$ of the world's wetlands in the past 40 years, and the threats to wetlands are growing through expanding agriculture, urbanization, pollution, over-exploitation of water resources and climate change;

Whereas wetlands are the most biodiverse and productive of all ecosystems, vital for their water and carbon storage and cycling functions which sustain the world's climate system;

Whereas wetlands are intrazonal ecosystems, the qualitative significance of which in Chinese history is indicated by their Chinese geographic identification, as different wetland types induced different cultures over time;

Whereas healthy wetlands support a beautiful and healthy earth, sustain happy lives and improve all human communities, especially for those living in cities; what is called 'Jiangnan (south China) culture' or 'waterside culture' originates from the word 'wetland culture', which has a long history;

Whereas there are about 53.6 million hectares of wetlands in China, which will be effectively managed by the government;

Recognizing wetlands including lakes, marshes, rivers, coastal zones, and artificial wetlands, with multiple ecosystem services providing a diversity of regulatory, provisioning and supporting services, including those that sustain the livelihoods and well-being of local communities;

Recognizing the value of wetlands in urban flood control and improving the health of city dwellers, and noting the prestigious Wetland City label to be awarded under the Ramsar Convention on Wetlands;

Recognizing the need to allocate an adequate quantity, and quality of water flowing with appropriate timing to enable the sustainable functioning of wetland ecosystems, within a legal framework, as set out in Resolution 12 of the $12^{\text {th }}$ Conference of the Contracting Parties to the Ramsar Convention;

Recognizing the need for increased wetland monitoring, assessment, national wetland inventories and earth observation, moving towards the establishment of a Global Wetlands Observation System;

Therefore call upon financial institutions worldwide - development banks, investment banks, ministries of finance - to invest in the conservation, wise use and restoration of wetlands for their 
unique biodiversity, carbon capture and carbon storage functions, and to reduce climatic variability and water risks;

Therefore call upon the private actors and the business sector to consider their supply chains, and to ensure that wetlands are not harmed or destroyed by their business practices, for long-term sustainability;

Therefore call upon farming communities and the agriculture sector to acknowledge that wetlands must be conserved and restored within agricultural landscapes, for sustaining biodiversity and pollination services, recharging aquifers and buffering the risks of droughts and floods;

Therefore call upon land use planners to recognize wetlands as a valuable global public good, and to ensure that wetlands are protected and embedded within both urban and rural landscapes;

Therefore call upon river basin managers and catchment committees concerned with issues of water allocation, to recognize upstream wetlands as valuable water providers, and downstream wetlands as essential water retention and detention infrastructure, for flood management, for aquifer recharge and for biodiversity within the basin, catchment or watershed;

Therefore call upon coastal development planners and authorities to recognize the critical importance of coastal wetlands, particularly intertidal areas, for the conservation of globally important migratory waterbird species and other valuable ecosystem services and ensure their protection and sustainable management;

Therefore call upon urban managers to enhance the beauty of their cities by restoring and valuing their wetlands, for urban flood control, for eco-tourism, for children's education, and for providing health and happiness to local urban dwellers. We encourage them to strive for accreditation of their city as a Wetland City under the Ramsar Convention on Wetlands.

We thank the Government of the People's Republic of China, Nanjing University, Changshu Government and - Nanjing University Ecological Research Institute of Changshu, and the other organizations for hosting, sponsoring and contributing to the 10th INTECOL International Wetlands Conference.

We acknowledge the success of this conference BY ACCLAMATION.

Signed on behalf of the participants in Changshu, People's Republic of China on 24 September 2016 by R. Eugene Turner, Jos T. A. Verhoeven, Ania Grobicki, Jenny Davis and Shuqing An

Ania Grobicki, Ramsar Convention on Wetlands, grobicki@ramsar.org 
翻译稿 (Translation)

\section{湿地常熟宣言 \\ 第十届国际湿地大会采纳的最终决议}

2016 年 9 月 19 24 号, 中国常熟

今天, 来自 XX 个国家的 $\mathrm{xxx}$ 名湿地科学、技术、政策和管理领域的专家齐聚于第十届国际湿地 大会，共同见证这个历史性的时刻。在此，众位专家达成如下共识：

\section{鉴于}

世界各国达成共识，可持续发展应包含下列重要目标：

（1）保护和恢复湿地、河流、含水层和湖泊等水体生态系统;

（2）可持续管理和保护海洋、沿海生态系统, 采用行之有效的修复方法, 增强其恢复力, 使其恢 复到健康状态;

（3）履行国际协议义务, 保护、恢复和可持续利用陆地和内陆淡水生态系统及其服务功能;

\section{鉴于}

过去的四十年间, 由于农业的扩大、城市化、水资源过度开发和气候变化, 直接或间接导致世界 上 $40 \%$ 的湿地消失;

\section{鉴于}

中国湿地历史源远流长，不同类型湿地在中国历史上由特殊不同的地理名词表示，代表了不同文 化;

\section{鉴于}

中国有 5,360 万公顷湿地被官方认定为 “国家湿地保护红线” , 中国政府会确保这些湿地受到保 护;

\section{鉴于}

常熟景色宜人, 湿地资源丰富, 湿地类型多样, 如河流湿地、湖泊湿地、沼泽湿地、人工湿地, 湿地率高达 $42 \%$ ，自然湿地面积为 2.25 万公顷，自然湿地保护率达 $50.1 \%$; 因此，常熟向湿地国 际申请湿地城市认证。

\section{认识到}

湿地的保护、恢复和管理以及湿地的脆弱性具有全球性意义; 湿地在生物多样性、储水和储碳方 面发挥的效力极大影响全球气候;

\section{认识到}

湿地在城市防洪、保证城市居民健康具有重要作用; 湿地公约认证的湿地城市具有长远意义;

\section{认识到}

湿地公约第 12 次缔约方会议第十二条决策认为, 应建立完善的水网确保湿地生态系统的可持续发

展;

认识到

湿地监测、评估、地球观测、湿地与互联网、政府间地球湿地观测组具有重要意义; 


\section{认识到}

健康湿地系统可为人类提供健康生活, 湿地建设让城市更好; 中国 “江南文化” 或 “水乡文化” 起源于“湿地文化”, 源远流长

\section{呼吁}

全球范围内的金融机构、部门、投资银行来为碳补货和减少水资源风险进行投资，以此来保护恢 复湿地;

\section{呼吁}

农业社区和农业部门在农业领域恢复湿地, 以保护生物多样性, 增益植物繁殖, 防止洪涝灾害;

\section{呼吁}

规划者认识到湿地是具有全球人民的公共利益，并在城乡景观规划过程中保护湿地;

\section{呼吁}

流域管理和流域委员会关心水分配的问题, 重视上游湿地的水源价值和下游湿地的保水价值, 从 而增强流域洪水管理、提高流域生物多样性;

呼吁

城市管理者通过恢复和评估湿地来美化城市, 为城市防洪, 为城市居民提供健康和幸福。我们敦 促他们争取湿地公约的湿地城市认证

\section{公开鸣谢}

感谢中华人民共和国、南京大学、常熟市人民政府以及南京大学常熟生态研究院, 感谢为第十届 国际湿地大会做出卓越贡献的各主办单位、协办单位、支持单位和其他单位。

我们在此宣布, 第十届国际湿地大会取得圆满成功。

参会代表签名:

R. Eugene Turner, Jos T. A. Verhoeven, Ania Grobicki, Jenny Davis，安树青 2016 年 9 月 24 日于常熟 